Reprod. Nutr. Dévelop., 1985, 25 (4 A), 659-669.

\title{
In vivo cholesterol synthesis by the rat digestive tract. II. A Study of turnover
}

\author{
Martine PERRODIN, Colette SÉROUGNE, C. LUTTON
}

Laboratoire de Physiologie de la Nutrition, ( ${ }^{1}$ ) Université de Paris-Sud, Bât. 447

91405 Orsay Cedex, France

Summary. In the main organs of the digestive tract of rats fed a semi-purified diet containing $0.5 \%$ cholesterol, cholesterol activity was measured $70 \mathrm{~min}$ and 8,24 and $48 \mathrm{~h}$ after subcutaneous impulsion of ${ }^{14} \mathrm{C}$-acetate or intravenous injection of tritiated water.

Cholesterol synthesized in the stomach and caecum-colon was not significantly renewed during the 48-hour experiment. On the contrary, cholesterol synthesized in situ in the intestine disappeared with a mean rate constant of $4 \% . \mathrm{h}^{-1}$. The rate constant (K) varied $\left(6 \% . \mathrm{h}^{-1}\right.$ in the duodenum and jejunum and about $3 \% \cdot \mathrm{h}^{-1}$ in the distal ileum) according to the site of the enterocytes in the small intestine. Cell sloughing could not account for the major part of the decrease in cholesterol radioactivity, particularly in the first three quarters of the small intestine. In the proximal half of the gut internal cholesterol secretion via lipoproteins poured into the lymph might play a role.

\section{Introduction.}

In a previous article (Perrodin and Lutton, 1985) we, like Andersen and Dietschy (1979) and Sugano et al. (1982), observed that the rate of intestinal cholesterol synthesis varied widely according to the location of the enterocytes on the villi and in the small intestine ; in rats fed a semi-purified diet the in vivo incorporation of ${ }^{14} \mathrm{C}$-acetate or ${ }^{3} \mathrm{H}_{2} \mathrm{O}$ into cholesterol was higher in the crypt cells than in the apical cells in the proximal as well as in the distal intestine. Under these nutritional conditions, cholesterogenesis was more active in the duodenum than in the proximal ileum. After synthesis in the reticulum, cholesterol is transferred to all the intracellular membranes in about $10 \mathrm{~min}$ (De Grella and Simoni, 1982) and is then renewed (Chevallier and Vyas, 1963 ; Wilson and Reinke, 1968 ; Ho and Taylor, 1974). Several studies have directly or indirectly proved the existence of synthetic intestinal cholesterol turnover, but very few have estimated its rate constant (Peng et al., 1973).

The present paper deals with the kinetics of cholesterol specific activity measured in the enterocytes collected from various sites on the villi and in the

(1) UA 646, C.N.R.S. - Unité alliée à I'I.N.S.E.R.M. (Prof. C. Lutton). 
small intestine at different times after ${ }^{14} \mathrm{C}$-acetate or ${ }^{3} \mathrm{H}_{2} \mathrm{O}$ administration. After a subcutaneous pulse of ${ }^{14} \mathrm{C}$-acetate, the radioactivity of the acetate pool reaches a peak $30 \mathrm{~min}$ later, then decreases. Thus, cholesterol is synthesized from a precursor having a high specific activity for a short period. We thought that a study of the decrease of cholesterol specific activity with time would provide a good index of the turnover rate of synthesized cholesterol. After an intravenous injection of tritiated water, body water quickly reaches isotopic equilibrium. In an organ with very slow cholesterol turnover, synthesized cholesterol should accumulate as a nearly linear function of time. In an organ with rapid cholesterol turnover, the amount of newly-synthesized cholesterol would plateau at a nearly constant rate.

\section{Materials and methods.}

The material and methods have been described in detail in a previous article (Perrodin and Lutton, 1985). Briefly, adult male Wistar rats, weighing $350 \pm 30 \mathrm{~g}$, were fed ad libitum a semi-purified diet (Chevallier et al., 1975) with $0.5 \%$ cholesterol for 3 weeks.

Thirteen rats (group $A$ ) received a subcutaneous injection of $\left[1-{ }^{14} \mathrm{C}\right]$-acetate $(200 \mu \mathrm{Ci} / 0.2 \mathrm{ml}$ saline) and were killed $70 \mathrm{~min}$ and 24,48 (at $10 \mathrm{a} . \mathrm{m}$.) and 8 (at 5 p.m.) hours after the injection. Furthermore, to compare the results obtained between the rats killed at 10 a.m. and those killed at 5 p.m., two lots of 4 rats each received $\left[1-{ }^{14} \mathrm{C}\right]$-acetate and were killed at 10 a.m. (group $\mathrm{A10}$ ) or $5 \mathrm{p} . \mathrm{m}$. (group A17) $8 \mathrm{~h}$ after the injection (preliminary experiment using acetate).

Three rats (group E) received an intravenous injection of $131 \mathrm{mCi}$ of $\left[{ }^{3} \mathrm{H}\right]-$ water in the penis vein. They were killed $70 \mathrm{~min}$ and 8 or $24 \mathrm{~h}$ after precursor administration.

The liver, stomach, small intestine and caecum plus colon were taken after the blood had been collected and the circulatory system washed several times with physiological saline. The small intestine was divided into four equal quarters. The contents of the stomach, small intestine and caecum-colon were collected after washing the walis with a Weiser solution (A) $(\mathrm{NaCl} 154 \mathrm{mM}$, sodium citrate $27 \mathrm{mM}, \mathrm{KH}_{2} \mathrm{PO}_{4} 8 \mathrm{mM}, \mathrm{Na}_{2} \mathrm{H} \mathrm{PO}_{4}, 5.6 \mathrm{mM}, \mathrm{pH} \mathrm{7.3)}$ for $15 \mathrm{~min}$ at $37^{\circ} \mathrm{C}$. The moderating action of a second solution (D) $\left(\mathrm{NaCl} 137 \mathrm{mM}, \mathrm{KCl} 2.69 \mathrm{mM}, \mathrm{Na}_{2} \mathrm{H}\right.$ $\mathrm{PO}_{4} 8.10 \mathrm{mM}, \mathrm{KH}_{2} \mathrm{PO}_{4} 1.47 \mathrm{mM}$, EDTA $1.5 \mathrm{mM}$, dithiothreitol $0.5 \mathrm{mM}, \mathrm{pH} 7.4$ ) at $37{ }^{\circ} \mathrm{C}$ enabled us to collect enterocytes located at the top of the villi (fractions 13 ), in the middle (fractions 4-6) and in the crypts (fractions 7-9).

The chemical and isotopic techniques have also been described. $\left[1-{ }^{14} \mathrm{C}\right]-$ acetate and ${ }^{3} \mathrm{H}_{2} \mathrm{O}$ were from the CEA (France). After saponification of the samples in alcoholic $2 \mathrm{~N} \mathrm{KOH}$ for $2 \mathrm{~h}$, the sterols were extracted with petroleum ether and precipitated with digitonin by the Sperry and Webb (1950) method. This was followed by pyridine breakdown of the digitonide complex and the sterols were dissolved in ethylic ether. Cholesterol was then quantitatively determined after separation on TLC or GLC (Sulpice et al., 1978), if necessary. Cholesterol radioactivity was measured in a PPO/dimethyl-POPOP/toluene solution with a liquid scintillation spectrometer (MR 300, Kontron). DNA was measured as described by Croft and Lubran (1965) and protein according to Gornall et al. (1949). 


\section{Results.}

Preliminary experiment using acetate (groups A10 and A17). - Table 1a shows that cholesterol concentration in the plasma, liver and intestine and the quantity of cholesterol in the last two organs were not significantly different in the two groups, A10 and A17. Cholesterol radioactivity in the plasma, liver and various areas of the small intestine are shown in table 1b. Except for the second quarter of the intestine, in which sterol radioactivity was greater at $5 \mathrm{p} . \mathrm{m}$. than at 10 a.m., none of the other values were significantly different in either group of rats. Cholesterol specific activity in the various enterocytes is shown in table 1c.

\section{TABLE 1a}

Cholesterol concentration (free and esterified) in the red cel/s, plasma, and liver and total cholesterol content in the liver and small intestine of rats killed at 10 a.m. (group A10) or 5 p.m. (group A17)

\begin{tabular}{|c|c|c|c|c|c|c|c|}
\hline & \multirow{2}{*}{ Red cells } & \multicolumn{2}{|c|}{ Plasma } & \multicolumn{2}{|c|}{ Liver } & \multirow{2}{*}{ Liver } & \multirow{2}{*}{$\begin{array}{c}\text { Small } \\
\text { intestine }\end{array}$} \\
\hline & & free & esterified & free & esterified & & \\
\hline & $\mathrm{mg} / \mathrm{g}$ & \multicolumn{2}{|c|}{$\mathrm{mg} / \mathrm{ml}$} & \multicolumn{2}{|c|}{$\mathrm{mg} / \mathrm{g}$} & $\mathrm{mg}$ & $\mathrm{mg}$ \\
\hline A10 & $\begin{aligned} & 1.41 \\
\pm & 0.01\left(^{*}\right)\end{aligned}$ & $\begin{array}{r}0.21 \\
+0.04\end{array}$ & $\begin{array}{r}0.80 \\
\pm 0.13\end{array}$ & $\begin{array}{r}2.07 \\
+0.09\end{array}$ & $\begin{array}{r}12.5 \\
-1.2\end{array}$ & $\begin{array}{r}276 \\
\pm \quad 31\end{array}$ & $\begin{array}{r}17.3 \\
\pm \quad 1.5\end{array}$ \\
\hline A17 & $\begin{array}{r}1.42 \\
\pm 0.03\end{array}$ & $\begin{array}{r}0.21 \\
+0.02\end{array}$ & $\begin{array}{r}0.63 \\
+0.06\end{array}$ & $\begin{array}{r}2.35 \\
+0.13\end{array}$ & $\begin{array}{r}15.5 \\
\pm 0.6\end{array}$ & $\begin{array}{r}336 \\
\pm 11\end{array}$ & $\begin{array}{r}16.4 \\
\pm 0.7\end{array}$ \\
\hline
\end{tabular}

$\left({ }^{*}\right\rangle$ Mean $\pm \operatorname{SEM}(n=4)$.

Again, there was no significant difference between the two groups of rats as to the cells collected from the duodenum or the proximal and distal ileum. Only the cholesterol specific activity of the enterocytes located at the top and the middle of the villi in the second quarter of the small intestine was higher in rats killed at 5 p.m.

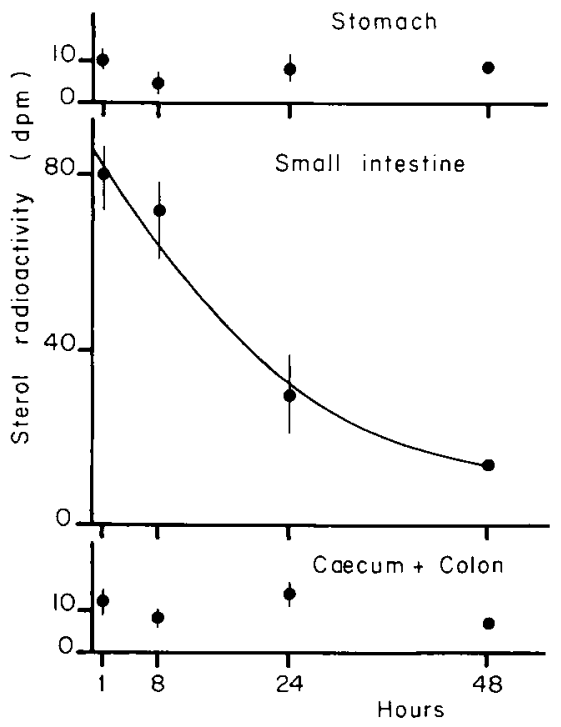

FIG. 1. - Profile of sterol radioactivity in relation to time in the stomach, intestine and caecum-colon of rats receiving a subcutaneous injection of $\left[1-{ }^{14} \mathrm{C}\right.$-acetate (group A). 


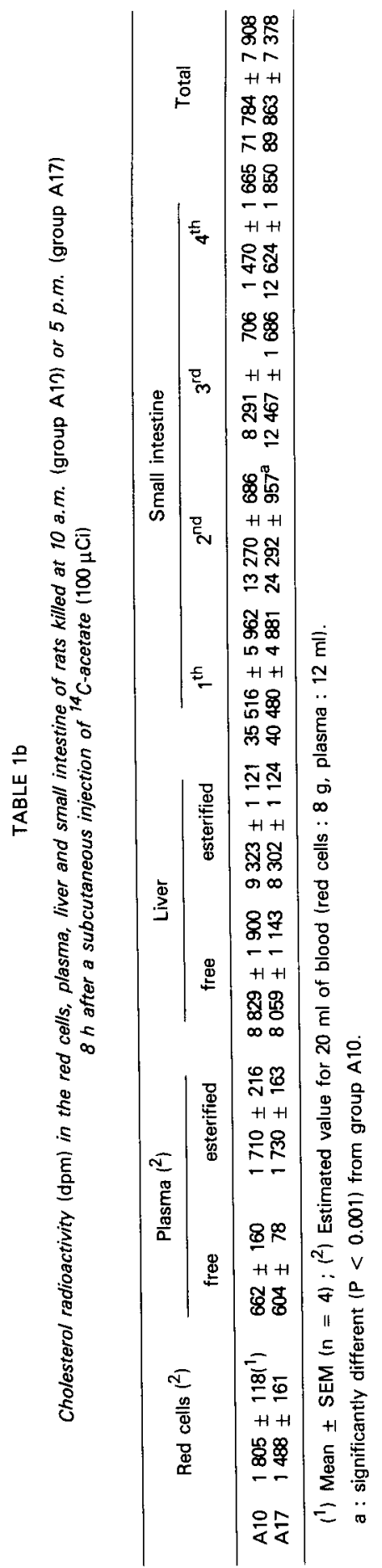

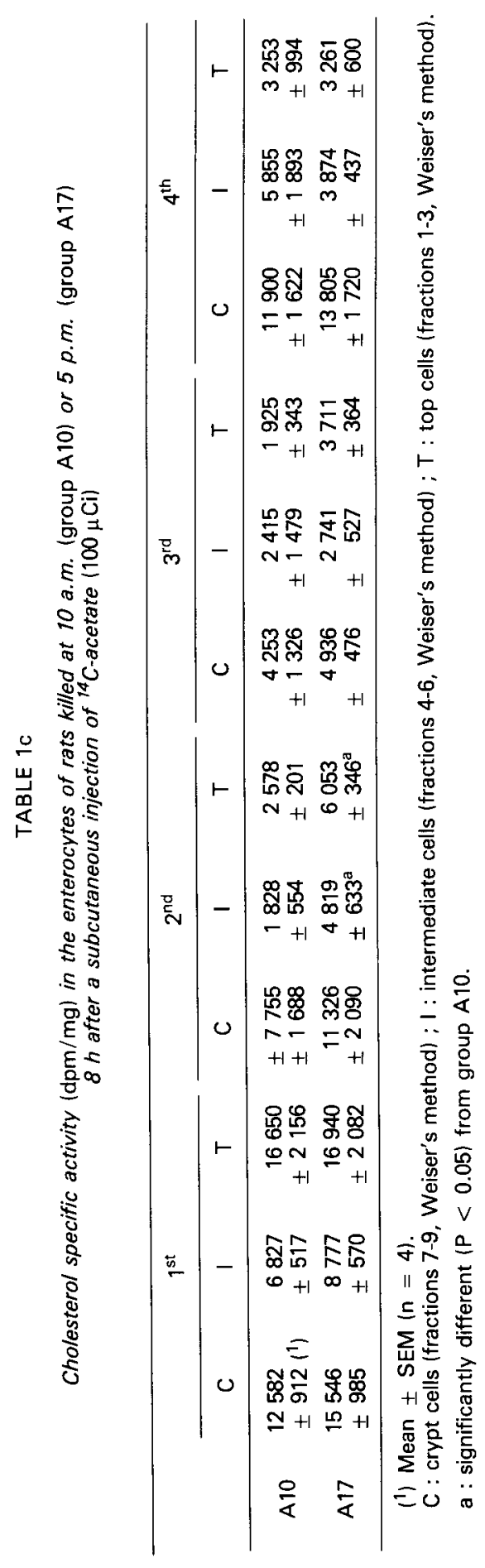


The experiment demonstrates that in our experimental conditions, the rates of cholesterol synthesis in the liver, plasma and major part of the small intestine at $10 \mathrm{a} . \mathrm{m}$. were not significantly different than those measured at $5 \mathrm{p} . \mathrm{m}$. The increase in cholesterol specific activity in the top jejunal enterocytes in rats killed at 5 p.m., the period of the day when luminal cholesterol content is lowest in rats (Chevallier and Lutton, 1972), suggests that luminal cholesterol may influence intestinal cholesterogenesis.

Main experiment (group A). - The variation of sterol radioactivity with time in the main digestive organs over the 48-hour period is illustrated in figure 1.

The radioactivity of cholesterol synthesized in situ in the stomach as well as in the caecum-colon remained constant throughout the experiment. The turnover of synthesized cholesterol in these tissues seemed non-significant during the 48hour period of observation. On the contrary, 70 min after precursor administration, cholesterol radioactivity in the small intestine was $\mathbf{8}$ times higher than in the stomach or the caecum-colon and decreased rapidly with an apparent $t 1 / 2$ of 16-20 h. As noted in our previous article, most (about $70 \%$ ) of this radioactivity was found in the first half of the small intestine. So, $70 \mathrm{~min}$ or $8 \mathrm{~h}$ after precursor administration, the respective contributions of the four intestinal quarters were : 1st quarter : $38-42 \% ; 2$ nd : $27-32 \%$; 3rd : 13-14 \% ; 4th : 17-17\%. During the experimental period, sterol radioactivity in the luminal content was very low compared with that of the wall (data not tabulated), representing only $4 \%$ of wall sterol radioactivity at $70 \mathrm{~min}$ and $8 \mathrm{~h}$, and less than $9 \%$ at 24 or $48 \mathrm{~h}$. The ileal content accounted for two-thirds of the total luminal sterol radioactivity. Furthermore, the part of cholesterol radioactivity in the small intestine wall and associated with the enterocytes represented $90,86,70$ and $45 \%$ after $70 \mathrm{~min}$ and 8,24 and $48 \mathrm{~h}$, respectively. The increase in cholesterol radioactivity with time in

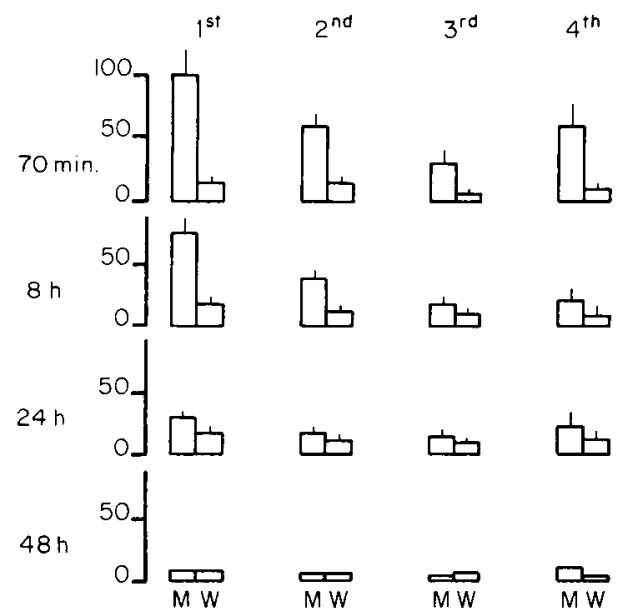

FIG. 2. - Profile of sterol specific activity in the small intestine in relation to time in rats receiving a subcutaneous injection of $\left[1{ }^{14} \mathrm{C}\right.$-acetate (group A).

The cells were collected from the small intestine divided into four equal quarters 11st, 2nd, 3rd, 4th).

$M$ : mucosa ; $W$ : remaining wall. 
the remaining wall after enterocyte collection was probably due to a slow transfer of synthesized cholesterol from the enterocytes. Cholesterol specific activity in the mucosa and the remaining wall is represented as a function of time in the four intestinal quarters in figure 2 . The highest value was observed in the duodenal mucosa $70 \mathrm{~min}$ after injection. Cholesterol specific activities were lower in the remaining wall than in the mucosa for $24 \mathrm{~h}$ and at all the intestinal levels. They decreased with time in the mucosa, whereas they remained almost constant in the remaining wall during the first $24 \mathrm{~h} ; 48 \mathrm{~h}$ after injection, these specific radioactivities became equal in the mucosa and in the remaining wall.

The variation of cholesterol specific activity in the various enterocytes as a function of time and intestinal quarter is shown in table 2. During the first $24 \mathrm{~h}$ after ${ }^{14} \mathrm{C}$-acetate injection, cholesterol specific activity was higher in the crypt than in the top cells in all the quarters. This difference was less pronounced in the duodenum than in the other intestinal quarters. In contrast, the decrease in cholesterol specific activity as a function of time was slower in the ileum than in the 1st quarter. For example, when cholesterol specific activities in the crypt cells were plotted as a function of time, the exponential curves obtained for the four quarters of the small intestine, from duodenum to distal ileum, had respective $K$ values of $6.2,6.1,5.3$ and $3.9 \% . h^{-1}$ (fig. 3 ).

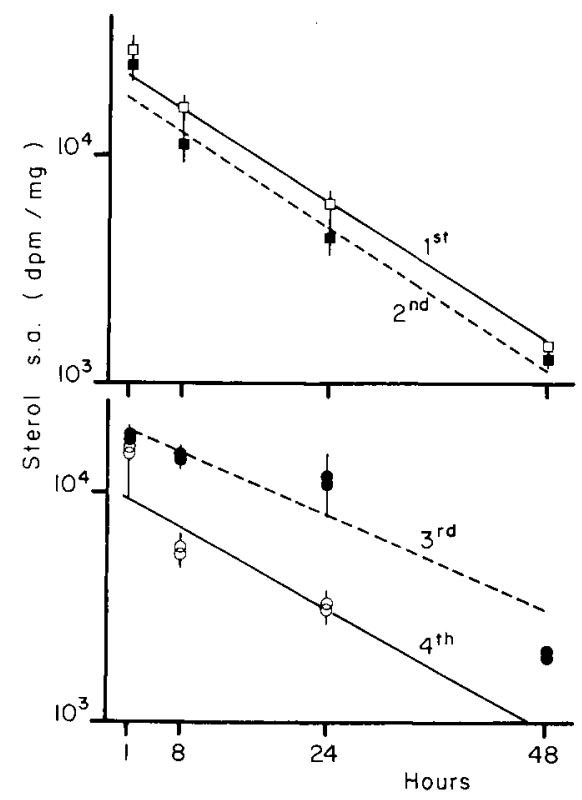

FIG. 3. - Profile of sterol specific activity in crypt cells of the small intestine in relation to time in rats receiving a subcutaneous injection of $\left[1-{ }^{14} \mathrm{C}\right.$-acetate (group $\mathrm{A}$ ).

Mean \pm SEM.

The cells were collected from the small intestine divided into four equal quarters (1st, 2nd, 3rd, 4th). 


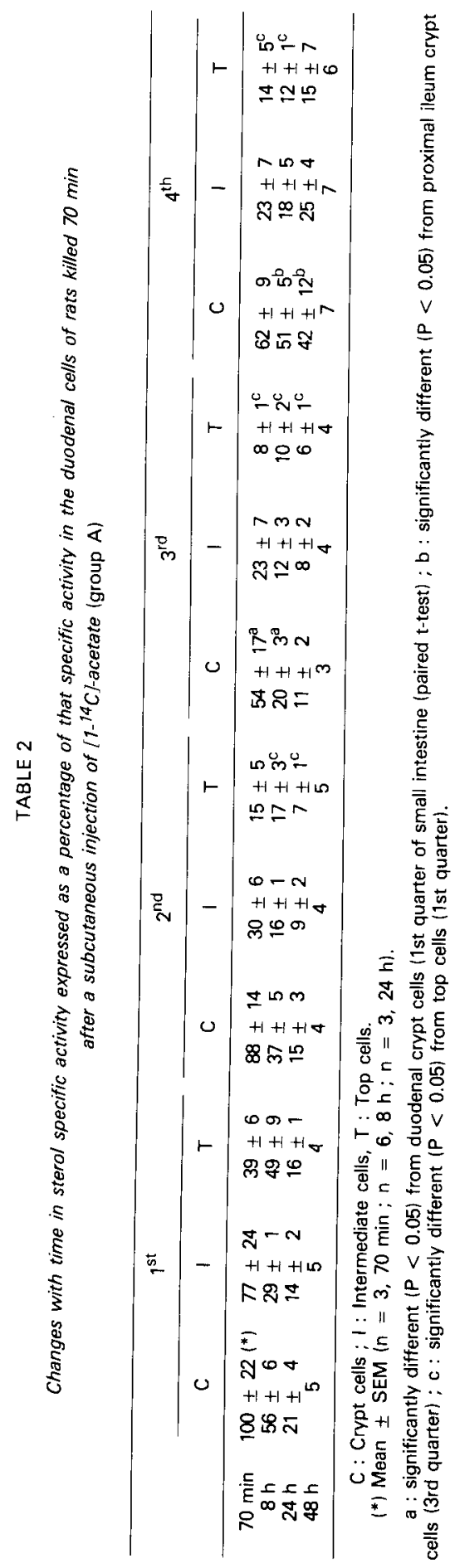




\section{Discussion.}

Kinetic study of cholesterogenesis in the digestive tract.

Stomach and caecum-colon. - Cholesterol radioactivity in the stomach and in the caecum-colon remained unchanged for $48 \mathrm{~h}$ after ${ }^{14} \mathrm{C}$-acetate injection (fig. 1), suggesting that cholesterol synthesized in these organs had no turnover. But, as in the small intestine, is has been shown that the mucosal cells of the organs are regularly poured into the lumen with a migration time of 2-3 days (Eastwood, 1977). Moreover, cholesterol is exchanged between the plasma, stomach and caecum-colon. These exchanges are slightly lower than for the intestine (Lutton and Brot-Laroche, 1980). These two processes should lead to a progressive decrease in the radioactivity incorporated into cholesterol after ${ }^{14} \mathrm{C}$ acetate injection. The relative constancy of this radioactivity over $48 \mathrm{~h}$ could be explained by the short observation time.

Small intestine. - As for the crypt cells from the four intestinal quarters, cholesterol specific activity (and cholesterol radioactivity) of the whole intestine decreased as a function of time according to an exponential curve. If the model for the turnover of cholesterol synthesized in the intestine is assumed to be an open compartment having 2 outputs, fecal elimination (RE) and transfer into plasma (RI) (fig. 4), then $K=4.1 \% . h^{-1}$ represents the sum of $K E$ and $K I$, an apparent constant rate. The fact that the mean ratio of sterol radioactivity in the luminal content to that lost by the mucosa in rats sacrificed after $8 \mathrm{~h}$ is about onethird, suggests that $\mathrm{KE}$ is about two times lower than $\mathrm{KI}$, i.e. approximately $1-1.5 \% \cdot h^{-1}$.

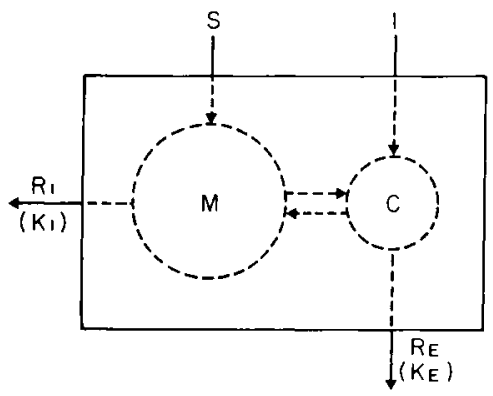

FIG. 4. - Simplified open one-compartment model of synthesized cholesterol in the small intestine. $\mathrm{M}$ : intestinal mucosa ; $\mathrm{C}$ : intestinal lumen ; $\mathrm{S}$ : synthesis ; I: ingestion; RI : internal secretion (KI rate constant for internal secretion) ; RE : fecal external secretion (KE rate constant for fecal external secretion). Simplified model from Magot et al., (1985).

In the mucosa crypt cells, the apparent constant rates reached $6.2 \% \cdot \mathrm{h}^{-1}$ (duodenum), $6.1 \% . \mathrm{h}^{-1}$ (jejunum), $5.3 \% . \mathrm{h}^{-1}$ (proximal ileum) and $3.9 \% . \mathrm{h}^{-1}$ (distal ileum). When considering the processes at the origin of synthesized cholesterol turnover in the intestine, two types of mechanisms are evident : cell renewal itself, or sloughing, and cholesterol turnover within the intestinal cell. In the different intestinal segments, cell renewal would lead to a cellular loss equal to $3 \% \cdot h^{-1}, 2 \% \cdot h^{-1}$ and $1.5 \% \cdot h^{-1}$ for the ileal, jejunal and duodenal mucosae, respectively (Miller et al., 1977). Consequently, only cell renewal could explain most of the decrease in cholesterol specific activity $\left(3.9 \% . \mathrm{h}^{-1}\right)$ in the ileal mucosa. Ori the contrary, other processes must be involved in the decline of 
cholesterol specific activity in the other three intestinal segments. Cholesterol synthesized in the intestine can also disappear from that organ by exchange with plasma cholesterol or association with lipoproteins secreted into the chyle. Previous results have shown that less than $1 \%$ of mucosal cholesterol is exchanged per hour with plasma cholesterol (Giraud-D'Hollander et al., 1976 ; Lutton and Brot-Laroche, 1980). Accordingly, this process would account for only a small part of the turnover of the cholesterol synthesized in the duodenal and jejunal enterocytes, but for a large part of the turnover of that synthesized in the ileal enterocytes. Finally, the secretion of lipoproteins containing cholesterol synthesized in the intestine would be the major process involved in cholesterol turnover in the duodenal and jejunal enterocytes. Such a localization agrees with the fact that chylomicrons and VLDL are secreted mainly in the first three quarters (or first half) of the small intestine in response to the absorption of dietary (or biliary) cholesterol (Lutton and Brot-Laroche, 1979).

\section{Internal and external secretion.}

Cholesterol synthesized in the intestinal mucosa is found either in the lumen (external secretion) or in the mobile pool (internal secretion) (Lutton, 1976). The relative parts of the first and second route have raised important questions in the minds of several authors (Chevallier and Vyas, 1963 ; Wilson and Reinke, 1968). Wilson and Reinke estimated that $50-70 \%$ of the cholesterol synthesized in the intestine is transferred into the lymph, the rest being poured into the lumen. This estimation is based on results from an experiment in which rats fed a commercial diet containing $0.5 \%$ cholesterol were intravenously injected with $\left[2-{ }^{14} \mathrm{C}\right]$-acetate. The authors measured the cumulated cholesterol radioactivity in lymph recovered from the cannulated lymphatic duct and in the lumen over a period of $48 \mathrm{~h}$. Previous results obtained in our laboratory under similar nutritional conditions showed that external fecal secretion of cholesterol was 3-5 mg per day (Mathé and Chevallier, 1979). Thus, intestinal contribution to internal secretion would be $6-10 \mathrm{mg} /$ day, i.e. the quasi-totality of the total intestinal secretion estimated by isotopic equilibrium methods in rats fed a cholesterol-enriched diet (Mathé and Chevallier, 1979). The present data allows an estimate of the participation of the different intestinal segments in these processes : the ratio of synthetic cholesterol transferred into the plasma to that transferred into the lumen would be $3 / 1$ in the proximal intestine and $1 / 3$ in the terminal ileum. Furthermore, since a large fraction of the cholesterol poured into the lumen from the first half of the intestine would be reabsorbed (Lutton and Brot-Laroche, 1979), the external secretion of fecal cholesterol would essentially result from cholesterol synthesized in the ileum, particularly in its distal portion.

Is there rapid exchange of synthesized cholesterol through enterocyte lateral membranes? - Assuming that cholesterol synthesis occurs only in crypt cells, the labelling recovered in other cells could be explained by rapid cholesterol exchange between the cells. At $70 \mathrm{~min}$, the cells fartherest from the crypts were the least labelled. Later, cholesterol specific activity became equal everywhere by way of both intercellular cholesterol exchange and cell migration. 
According to the second hypothesis, cholesterol synthesis would occur in all the mucosal cells but would be more intensive in the crypt than in the top cells. That cholesterol specific activities were progressively similar in all cells could be explained by cell migration alone. Further information on the existence and rate of interceliular cholesterol exchange is needed to definitively determine which hypothesis is correct.

Some authors have shown however that cholesterol synthesized in the endoplasmic reticulum is recovered $10 \mathrm{~min}$ later in enterocyte lateral membranes (De Grella and Simoni, 1982). At this time, a similar labelled cholesterol pattern is observed (data not shown). Actually, no results are available concerning the time necessary for synthesized cholesterol to pass from one cell to another, but in vitro experiments support the second hypothesis. Isolated apical and crypt cells have been shown to incorporate ${ }^{14} \mathrm{C}$-acetate into sterols (Strandberg et al., 1981). This incorporation is 6-9 times higher in crypt than in apical cells, whereas in our in vivo experiment it was 2.5 times higher in the duodenum and 6-7 times higher in the proximal ileum.

Reçu en décembre 1984. Accepté en avril 1985.

Acknowledgements. - The authors wish to thank M. Moque for the illustrations and Mrs Boivin for typing the paper.

Résumé. Synthèse de cholestérol dans le tractus digestif du rat. /l. Etude de son renouvellement.

Chez des rats ingérant un régime semi-synthétique contenant $0,5 \%$ de cholestérol, nous avons entrepris l'étude de l'évolution de la radioactivité spécifique du cholestérol dans le tube digestif, $70 \mathrm{~min}, 8,24$ et $48 \mathrm{~h}$ après injection sous-cutanée d'acétate $1{ }^{14} \mathrm{C}$ ou injection intraveineuse d'eau tritiée.

Le cholestérol synthétisé dans la paroi de l'estomac et du caecum plus côlon n'est pas l'objet d'un renouvellement sensible au cours des $48 \mathrm{~h}$ d'expérience. Par contre, dans l'intestin grêle, le cholestérol nouvellement synthétisé dans les entérocytes disparaît avec un taux moyen de $4 \% . \mathrm{h}^{-1}$. La vitesse de renouvellement du cholestérol de synthèse diffère cependant selon que les entérocytes se trouvent dans le duodénum ou le jéjunum $\left(6 \% . h^{-1}\right)$ ou l'iléum distal $\left(3 \% \cdot h^{-1}\right)$. La perte cellulaire ne peut être à l'origine de l'essentiel de la disparition du cholestérol de synthèse, en particulier pour les trois premiers quarts de l'intestin grêle. Dans l'intestin proximal, une sécrétion interne de cholestérol via les lipoprotéines du chyle est à prendre en compte.

\section{References}

ANDERSEN J. A., DIETSCHY J. M., 1979. Absolute rates of cholesterol biosynthesis in extrahepatic tissues with $3 \mathrm{H}$-labeled water and ${ }^{14} \mathrm{C}$-labeled substrates. J. Lipid Res., 19, 740-752.

CHEVALLIER F., LUTTON C., 1972. Mouvements des stérols dans le tube digestif du rat. Absorption du cholestérol de synthèse. Biochim. biophys. Acta, 274, 382-411.

CHEVALLIER F., SÉROUGNE C., CHAMPARNAUD G., 1975. Effect upon brain weight and cholesterol content of maintaining rats of various ages at constant weight. J. Nutr., 105, 1003-1011.

CHEVALLIER F., VYAS M., 1963. Les origines du cholestérol du chyle. Mise en évidence à l'aide de la méthode des indicateurs nucléaires. Bull. Soc. Chim. biol., 44, 253-276. 
CROFT D. N., LUBRAN M., 1965. The estimation of desoxyribonucleic acid in the presence of sialic acid : application to analysis of human gastric washings. J. Biochem., 95, 612-620.

DE GRELLA R. F., SIMONI R. D., 1982. Intracellular transport of cholesterol to the plasma membrane. J. biol. Chem., 257, 14256-14262.

EASTWOOD G. L., 1977. Progress in gastroenterology : gastrointestinal epithelial renewal. Gastroenterology, 72, 962-975.

GIRAUD-D'HOLLANDER F., MAGOT T., CHEVALLIER F., 1976. In vivo study of free and esterified cholesterol turnover in various rat tissues. Biochimie, 58, 855-862.

GORNALL A. T., BARDAWILL C. J., DAVID M. M., 1949. Determination of serum proteins by means of the biuret reactions. J. biol. Chem., 177, 751.

HO K. H., TAYLOR C. B., 1974. Sources of cholesterol in the intestinal lymph in rats fed a cholesterol free diet. Proc. Soc. exp. Biol. Med., 147, 826-829.

LUTTON C., 1976. The role of the digestive tract in cholesterol metabolism. Digestion, 14, 342-356.

LUTTON C., BROT-LAROCHE E., 1979. Biliary cholesterol absorption in normal and L-thyroxin-fed rats. Lipids, 14, $441-446$.

LUTTON C., BROT-LAROCHE, 1980. In vivo plasma cholesterol exchanges in the digestive tract of the rat : effect of L-thyroxine. Digestion, 20, 253-264.

MAGOT T., VERNEAU C., LUTTON C., CHEVALLIER F., 1985. Origin and fate of cholesterol in rat plasma lipoproteins in vivo. 1. Qualitative analysis. Ann. Nutr. Metab. (in press).

MATHÉ D., CHEVALLIER F., 1979. Effect of the level of dietary cholesterol on the dynamic equilibrium of cholesterol in rats. J. Nutr., 109, 2076-2084.

MILLER D., HANSON W., SCHEDL H. P., OSBORNE J. W., 1977. Proliferation rate and transit time of mucosal cells in small intestine of the diabetic rat. Gastroenterology, 73, 1326-1332.

PENG S. K., HO K. J., MIKKELSON B., TAYLOR C. B., 1973. Studies on cholesterol metabolism in rats by application of $\mathrm{D}_{2} \mathrm{O}$ and mass spectrometry. Atherosc/erosis, 18, 197-213.

PERRODIN M., LUTTON C., 1985. In vivo cholesterol synthesis by the rat digestive tract. I. A topological study. Reprod. Nutr. Dévelop., 25, $\mathrm{XXX}-\mathrm{XXX}$.

SÉROUGNE C., LUTTON C., 1982. Répartition du cholestérol d'origine plasmatique dans la villosité intestinale chez le rat. J. Physiol. Paris, 78, 170-174.

SPERRY W. M., WEBB M., 1950. A revision of the Schoenheimer-Sperry method for cholesteral determination. J. biol. Chem., 187, 97-106.

STRANDBERG T. E., TILVIS R. S., MIETTINEN T. A., 1981. Squalene and sterol synthesis in isolated small intestinal cells of the rat. Scand. J. Gastroenterol., 16, 801-810.

SUGANO M., FUJISAKI Y., OKU H., IDE T., 1982. 3-OH-3 methylglugaryl CoA reductase activity in the small intestine of rats fed non-purified and semi-purified diets. J. Nutr., 112, 51-59.

SULPICE J. C., FÉRÉZOU J., LUTTON C., MATHÉ D., CHEVALLIER F., 1978. Diet and sterol biohydrogenation in the rat : occurrence of epicoprostanol. Lipids, 13, 217-224.

WEISER M. M., 1973. Intestinal epithelial cell surface membrane glycoprotein synthesis. An indication of cellular differentiation. J. biol. Chem., 248, 2536-2541.

WILSON J. D., REINKE R. T., 1968. Transfer of locally synthesized cholesterol from intestinal wall to intestinal lymph. J. Lipid Res., 9, 85-92. 